\title{
From Bench to Market: Preparing Human Pluripotent Stem Cells Derived Cardiomyocytes for Various Applications
}

\author{
Sung-Hwan Moon ${ }^{1}$, Daekyeong Bae ${ }^{2}$, Taek-Hee Jung ${ }^{3}$, Eun-Bin Chung ${ }^{3}$, \\ Young-Hoon Jeong ${ }^{3}$, Soon-Jung Park ${ }^{3}$, Hyung-Min Chung ${ }^{3}$ \\ ${ }^{I}$ Department of Medicine, School of Medicine, Konkuk University, Seoul, Korea \\ ${ }^{2}$ Mirae Cell Bio Inc., Seoul, Korea \\ ${ }^{3}$ Department of Stem Cell Biology, School of Medicine, Konkuk University, Seoul, Korea
}

Human cardiomyocytes (CMs) cease to proliferate and remain terminally differentiated thereafter, when humans reach the mid-20s. Thus, any damages sustained by myocardium tissue are irreversible, and they require medical interventions to regain functionality. To date, new surgical procedures and drugs have been developed, albeit with limited success, to treat various heart diseases including myocardial infarction. Hence, there is a pressing need to develop more effective treatment methods to address the increasing mortality rate of the heart diseases. Functional CMs are not only an important in vitro cellular tool to model various types of heart diseases for drug development, but they are also a promising therapeutic agent for cell therapy. However, the limited proliferative capacity entails difficulties in acquiring functional CMs in the scale that is required for pathological studies and cell therapy development. Stem cells, human pluripotent stem cells (hPSCs) in particular, have been considered as an unlimited cellular source for providing functional CMs for various applications. Notable progress has already been made: the first clinical trials of hPSCs derived CMs (hPSC-CMs) for treating myocardial infarction was approved in 2015, and their potential use in disease modeling and drug discovery is being fully explored. This concise review gives an account of current development of differentiation, purification and maturation techniques for hPSC-CMs, and their application in cell therapy development and pharmaceutical industries will be discussed with the latest experimental evidence.

Keywords: Human pluripotent stem cell, Cardiomyocytes, Cell therapy, Drug discovery, Disease modeling

Accepted for publication April 27, 2017, Published online May 30, 2017 Correspondence to Hyung-Min Chung

Department of Stem Cell Biology, School of Medicine, Konkuk University, 120 Neungdong-ro, Gwangiin-gu, Seoul 05029, Korea Tel: +82-2-2049-6232, Fax: +82-2-455-9015

E-mail: stemchung@gmail.com

(c) This is an open-access article distributed under the terms of the Creative Commons Attribution Non-Commercial License (http://creativecommons.org/ licenses/by-nc/4.0/), which permits unrestricted non-commercial use, distribution, and reproduction in any medium, provided the original work is properly cited.

Copyright (C) 2017 by the Korean Society for Stem Cells Research

\section{Human pluripotent stem cells derived cardiomyocytes (hPSC-CMs) differentiation strategies}

Human embryonic stem cells (hESCs), induced pluripotent stem cells (hiPSCs) and nuclear transfer embryonic stem cells (Nt-ES), are all considered to possess pluripotency, although their derivation methods and origins differ. Such a capacity could provide an answer to overcoming the lack of cellular sources from which functional cardiomyocytes (CMs) can be obtained. In the last two decades, strenuous research efforts have made huge stride in developing efficient differentiation and purification methods for CMs, and their potential use in the areas of cell therapy development and new drug discovery is stead- 
ily being materialized. Recapitulating key developmental events of cardiogenesis has been a customary practice for inducing CMs differentiation. Such attempts have been conducted 1) through formation of 3-dimensional floating cell aggregates (embryoid bodies, EBs) that consist of three germ layers cells, 2) by directly supplementing differentiation milieu to monolayer of adherent hPSCs or 3) by co-culturing with supporting cells known to facilitate CMs differentiation (Fig. 1).

\section{D method using embryoid body (EB) formation}

Since the establishment of hESCs lines in 1998, and later hiPSCs in 2007, EBs formation has been a popular choice of method for inducing CMs differentiation. Floating hPSCs colonies spontaneously form spherical EBs that constitute cells representative of all three germ layers. Supplementation of a cocktail of growth factors to the suspension culture of EBs expedites CMs differentiation as some cells undergo perceptible morphological changes into contractile cells with sarcomeric structures as early as day 20 post growth factor treatment (1). However, the attempts to control the consistency and efficiency of
EBs based approaches are severely thwarted mainly due to the variability in the EB sizes. In recent years though, studies have reported various means to control the EB sizes in order to minimize differentiation variability associated with the size. For instance, micro aggrewell plates (commercialized by STEMCELL Technologies Inc), allow aggregation of a defined number of cells by simple centrifugation. The ease with which a large number of uniform size EBs can be produced paves the way for a simple and commercial scale production of differentiated cells (2).

\section{D-directed monolayer differentiation}

Monolayer differentiation of hPSCs is initiated without the intermediately $\mathrm{EB}$ formation stage, and differentiation cues are directly supplemented to the adherent hPSCs in feeder-free systems. One of the advantages of the monolayer differentiation is that it enables investigators to gain a better control of the differentiation. The morphological changes are easily observable under a light microscope therefore different growth factors can be supplied in a stage-specific manner in attempts to as closely recapitulate

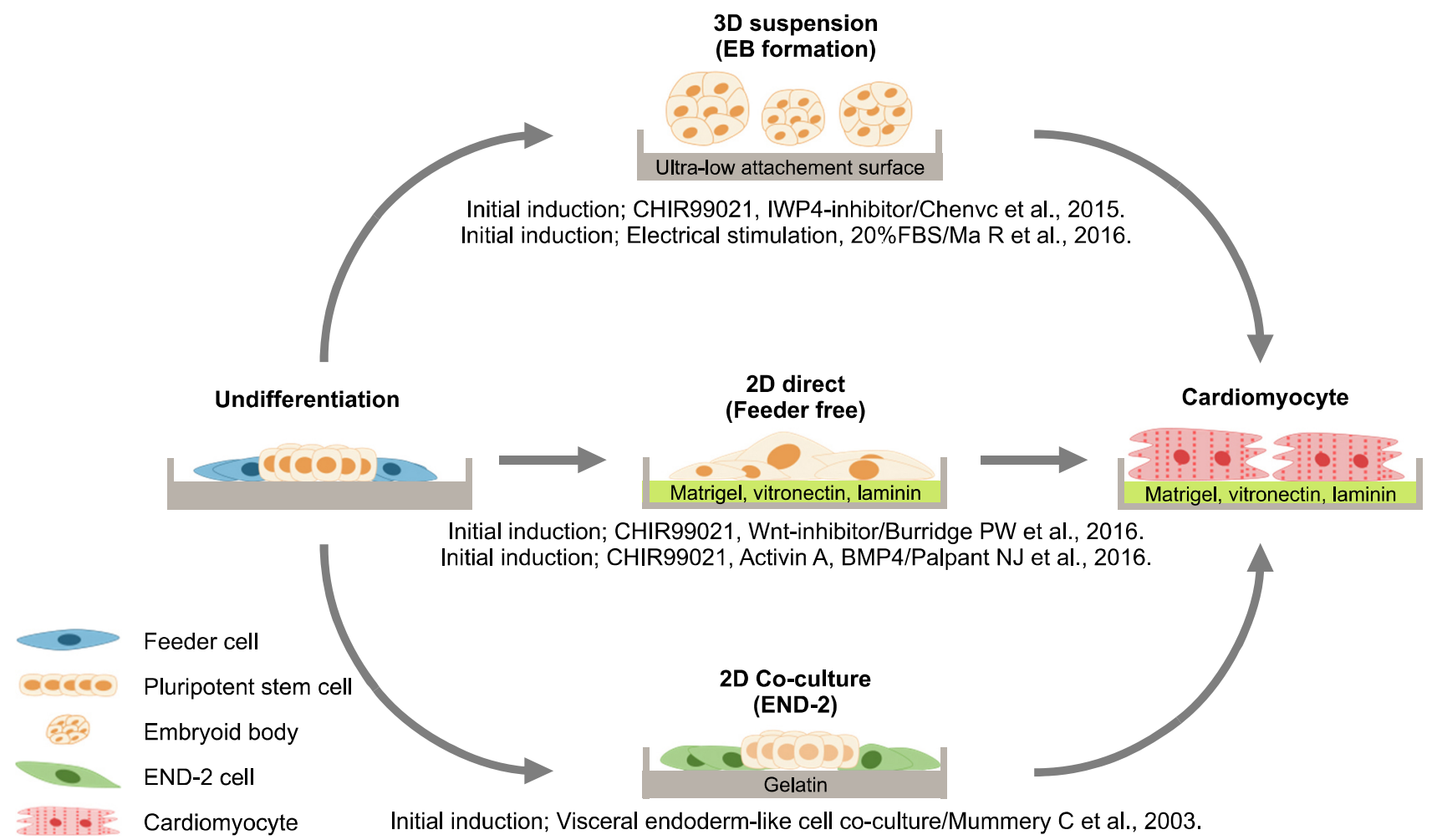

Fig. 1. Representative differentiation methods for hPSC-CMs. Differentiation strategies for hPSC-CMs can largely be divided into three most commonly used methods: via EB formation, 2D monolayer differentiation and co-culture system. The first two methods require supplementation of differentiation inducers (growth factors and small molecules) whereas these factors are redundant in the END-2 co-culture system. Abbreviations: EB: embryoid body, BMP4: bone morphogenetic protein 4. 
the embryonic environment as possible. 2D directed differentiation of CMs is often based on Wnt signaling pathway, and regulates the differentiation by adding growth factors such bone morphogenetic protein 4 (BMP4), Activin A and fibroblast growth factor 2 (FGF2) to the culture medium containing serum (3). Such method is, however, not suitable for clinical application of resulting CMs as the serum is an animal derivative. Xeno-free culture medium consisting of RPMI and B27 supplement has been developed, and together with above-mentioned growth factors, CMs differentiation efficiency between $50 \sim 90 \%$ was achieved (4). In recent years, small molecules, known for higher potency and lower manufacturing costs than growth factors, have been widely adopted for initiating CMs differentiation. GSK3-inbitiors (CHIR99021, BIO, TWS119, TDZE-8, 3F8) and wnt inhibitors (IWR-1, IWP2, IWP3, IWP-4, XAV-939, KY02111, WNt-C59) are commonly used small molecules for CMs differentiation yielding an efficiency between $80 \sim 90 \%(5,6)$.

\section{Co-culture system}

CMs differentiation is induced by culturing hPSCs with endoderm lineage cells that are known to play intricate, yet important roles for the heart development. A co-culture system of hPSCs with mouse visceral endoderm-like cells (END-2) has been reported to be conducive to generating contractile cells at an efficiency of about 25 to $40 \%$. Co-culture differentiation methods can induce differentiation using a small number of hPSCs, and has an advantage of achieving comparable differentiation efficiency within a relatively short period of time without a plethora of growth factors (7). However, there is a dis- advantage of having to separate differentiated CMs from the residual END-2 for subsequent applications.

\section{Characterization and purification of hPSC-CMs}

hPSC-CMs emerges sequentially from the undifferentiated state through the primitive mesoderm to CMs in an analogous manner to cardiogenesis during the early human developmental stage. In the initial stages of the differentiation, the expression of undifferentiated markers (e.g. Oct4 and Nanog) dissipates while inversely, the expression level of representative markers of early mesoderm differentiation increases (e.g. Brachyury and DKK-1). As the differentiation progresses, the differentiating cells take up immature CMs characteristics as demonstrated by CMs (e.g. NKX2.5 and Gata4) and muscle filament (e.g. cTnT, alpha-actin and MHC) associated markers expressions, spontaneous contractility and electrophysiological properties (Fig. 2) (8). Over time, such cells mature into fully functioning cells akin to adult CMs (1). Since the differentiation is never $100 \%$ efficient, the presence of contaminating by-products is inevitable, thus techniques for separating and purifying CMs are required (9). Current purification strategies, and probably one of the most used methods, include the following; centrifugation, flow cytometry and metabolic screening (Fig. 3).

\section{Centrifugation (percoll gradient)}

CMs purification by density gradient is somewhat considered as the "golden standard". Since CMs are larger and denser than non-CMs, density gradient centrifugation, in which cells are fractionated by floating density, could
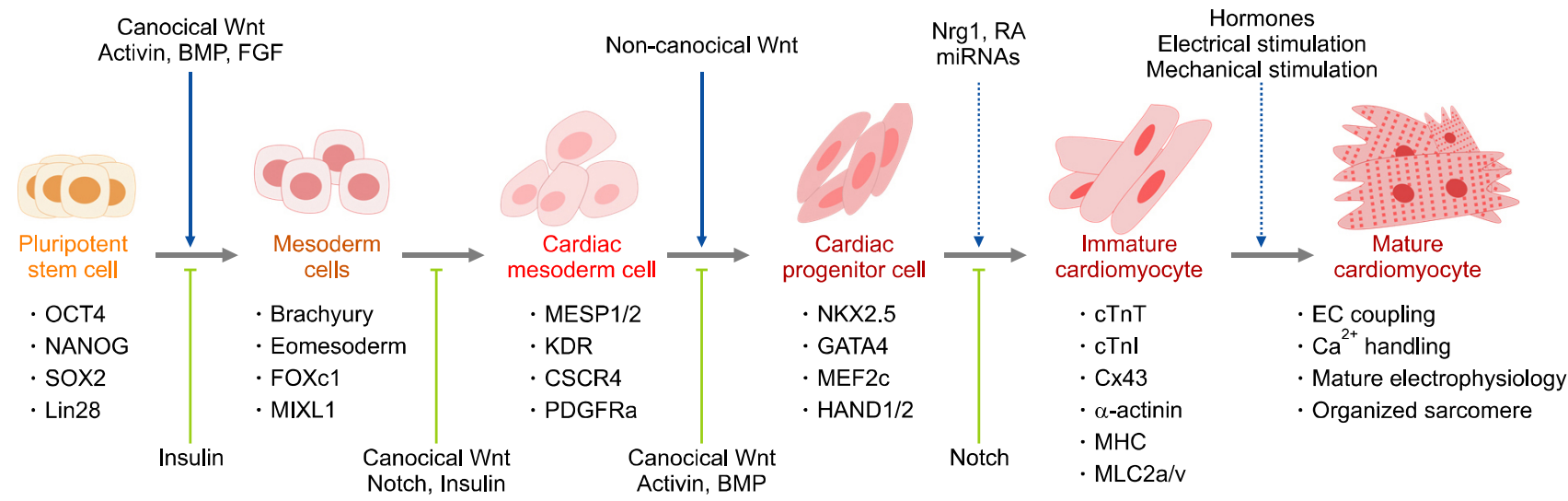

Fig. 2. Stage-specific differentiation inducers and cell characteristics. hPSC-CMs differentiation takes place sequentially as shown above. The cells exhibit distinct phenotypic and genotypic characteristics pertaining to a specific stage, where a combination of differentiation inducers is supplemented to proceed to the next stage. The final stage of the differentiation involves maturation of nascent and immature CMs. 


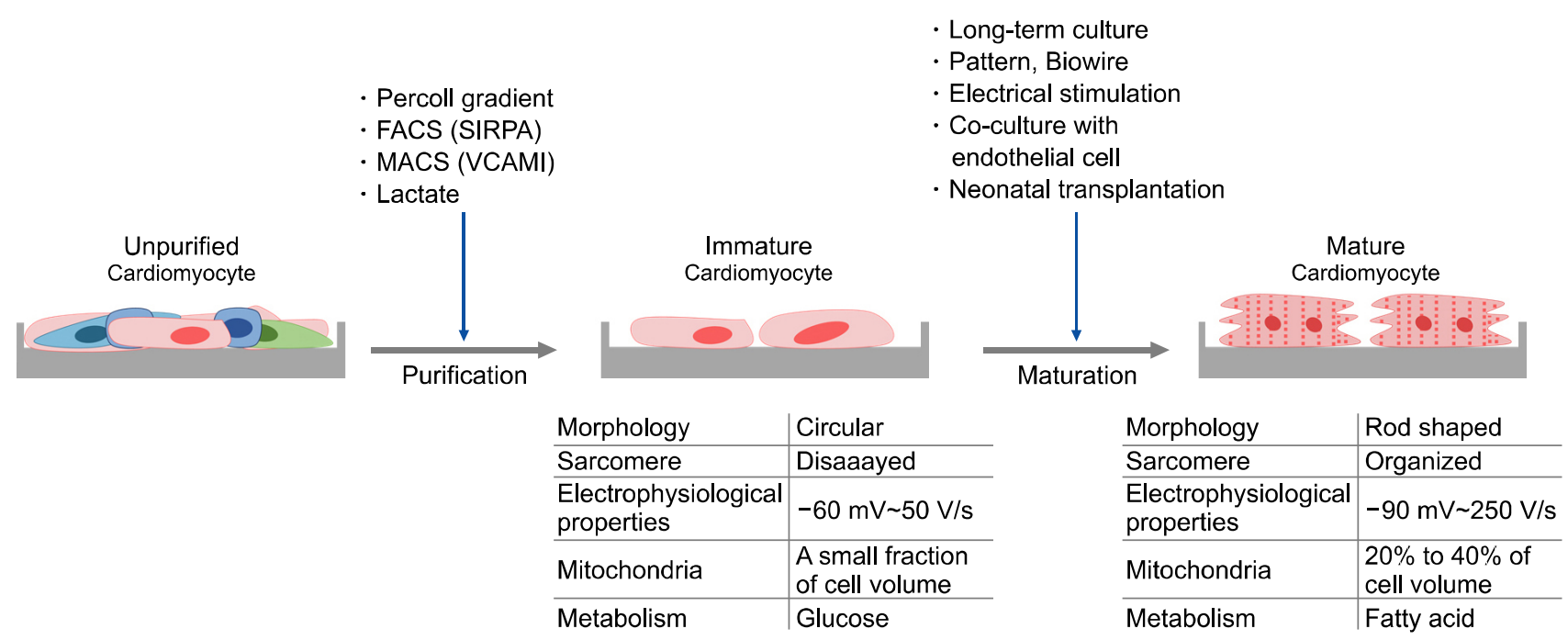

Fig. 3. Purification and maturation for hPSC-CMs. hPSC-CMs are enriched following the differentiation because the procedure inevitably yields by-products. The purified hPSC-CMs exhibit immature characteristics, as the differentiation methods are often completed 20-30 days after the initiation. Purification and maturation are prerequisite procedures for subsequent applications of hPSC-CMs. Abbreviations: FACs: fluorescence activated cell sorting, MACs: magnetic activated cell sorting.

effectively separate CMs from other cell types. This was routinely used to isolate primary CMs until 2000, when mouse ESCs derived CMs were first purified by the same method (10). Later, $\sim 60 \%$ hPSC-CMs were purified from impurities such as EBs, small clumps and single cells, and $\sim 82.6 \%$ CMs were enriched following a $2 \mathrm{D}$ directed method $(11,12)$.

\section{Flow cytometry}

Flow cytometry analysis using cell-specific markers has the advantage of being applicable to various cell types in a simple and highly efficient manner, but no marker specific to CMs has been reported. For this reason, many researchers have identified CMs related surface proteins during differentiation, and validated their authenticity as CMs specific markers. KDR and C-KIT (13) and Flk-1 and PDGFR- $\alpha$ (14) have been used to isolate hPSC-CMs progenitors, which were then further matured into functional CMs. Such purification methods yielded populations of $50 \%$ and $60 \%$ CMs respectively $(13,14)$. In 2011, signal-regulatory protein alpha (SIRPA) was found to be exclusively expressed in hPSC-CMs, and when an antibody against SIRPA was used to isolate CMs from the differentiating culture, it yielded up to $98 \%$ cTnT-positive cells (15). Vascular cell adhesion molecule 1 (VCAM1) has also been reported as a viable surface protein marker for isolating hPSC-CMs (16). After screening 242 antibodies for human cell surface molecules, it was found that $80 \%$ cTnT positive hPSC-CMs also expressed VCAM1 11 days post differentiation. Thus, purification using VCAM1 antibody at day 11 yielded $\sim 98 \%$ VCAM1 positive population of which $\sim 95 \%$ expressed cTnT, and displayed molecular and functional features of CMs.

\section{Gene modification}

Various reporter hPSCs lines have been generated to develop an efficient fluorescent-based purification method. The generation of a reporter hPSCs line harboring the green flourescence protein (GFP) Nkx2.5 gene was reported, and purification based on a high level of GFP fluorescence upon differentiation yielded $85 \%$ CMs $(17,18)$. The $\alpha$-myosin heavy chain ( $\alpha$ MHC) gene is broadly expressed during the course of murine cardiac development therefore its sensitivity for purifying hPSC-CMs was examined by constructing a myocardial-specific enhanced GFP reporter in H9 hESCs line (19). Using the cell line, the investigators were able to isolate myocardial precursors, which were capable of further developing into atrial- and ventricular-like CMs. CMs specific reporter cell lines serve the purpose of purifying CMs, but this method is an unlikely option for clinical applications.

\section{Metabolic selection}

Glucose is the primary energy source for metabolically active mammalian cells. Glycolysis breaks down glucose into pyruvate and lactate while generating two molecules of ATP without the presence of oxygen. Pyruvate is then used as a substrate in the mitochondrial tricarboxylic acid 
cycle to yield 36 ATP molecules via oxidative phosphorylation. CMs, unlike most somatic cells, are capable of using lactic acid as an alternative metabolic substrate under glucose-depleted environments. To attest this metabolic homeostasis, differentiating hPSCs culture was subjected to glucose-depleted environments with varying concentrations of lactate (20). Therein, non-CMs failed to survive as $\sim 98 \%$ alpha-actinin positive cells were detected $20 \sim$ 30 days after differentiation. The fact that hPSC-CMs had remained a high intracellular ATP in such environments revealed that the metabolic selection is an effective purification strategy for enriching viable and functional hPSC-CMs.

\section{Maturation methods for hPSC-CMs}

The action potential generated by ion channel activity in intracellular segmental structures is important for the spontaneous contractility of mature CMs. However, hPSC-CMs are immature in comparison to those derived from adult tissues in terms biological (cell morphology and contractility) and functional (cellular metabolism and electrophysiology) standpoint. Therefore, for the application of hPSC-CMs in cell therapy development and drug screening, the cells are required to resemble as closely as possible the fully fledged adult CMs in terms of functionality. Techniques such as 1) long-term culture, 2) biomimetic and tissue engineering techniques, and 3) electrical stimulation have been employed as methods to induce maturation of hPSC-CMs (Fig. 3).

\section{Characteristic comparison between immature hPSC-CMs and mature adult CMs \\ Morphological properties: Although mature human} adult CMs have a long rod-shaped arrangement of sarcomere structures, hPSC-CMs are smaller and have an irregular round segmental shape compared to mature CMs. The membrane capacitance, which increases in proportion to the cell surface area, is lower than adult CMs due to the size of immature CMs (21). In adult CMs, transverse tubules (T-tubules) that regulate the calcium release and contraction of the sarcoplasmic reticulum (SR) are well developed, but those in hPSC-CMs are poorly developed in comparison (22).

Electrophysiological properties: In order to generate action potentials of CMs, signal transmission systems between various ion channels must work in concert. However, in immature CMs, low activity among ion channels may cause impairment to spontaneous contractility, and unstable cell function may present crucial pitfalls in their applications. The gap junction, which regulates the conduction velocity of $\mathrm{CMs}$, is an important factor in determining the maturation of CMs. In the case of immature CMs, Connexin and N-cadherin are distributed circumferentially around the cell membrane, while those in mature CMs are distributed in the intercalated disks (23). Since the difference in the intracellular distribution of the gap junction proteins may attribute the functional differences of CMs, modulating the distribution of the gap junction protein is a very important for the stabilization of CMs function.

Metabolic properties: CMs are one of the most energy-demanding cells in the human body, and over 35\% of their volume is composed of mitochondria. The type of energy metabolism of CMs depends on their maturity. Not only mature adult CMs have higher mitochondrial numbers compared to hPSC-CMs, but the inner membranes of the mitochondria are also well developed. The mitochondrial oxidative capacity increases in the mature CMs, and $\sim 90 \%$ of energy generation is ascribed to fatty acid $\beta$-oxidation (24). Immature and proliferating CMs, in contrast, have fewer mitochondrial numbers, and they are functionally under developed. Indeed, oxidative metabolism only accounts for only $<15 \%$ of the total ATP produced, and their reliance on glycolysis is much preferred (25).

\section{Maturation method for hPSC-CMs}

Long term culture: hPSC-CMs are generated $20 \sim 30$ days post induction thus, it is inevitable that they are biologically, functionally and structurally immature in comparison to adult CMs that continue to mature for $6 \sim 10$ years after birth. A long-term culture protocol was devised to examine whether hPSC-CMs take up more mature characteristics over a prolonged period of time in culture (26). In this study, the early stage hPSC-CMs (20 40 days after initiating differentiation) were largely small and rounded cells with poor subcellular organizations, and an underdeveloped contractile machinery as evidenced by the misalignment of myofibrils. Morphological changes into more elongated shape were accompanied with an increased size over the ensuing 2 months, and by day 80 100 post differentiation induction, an improved myofibril alignment, density and morphology was observed. In addition, a 2-fold increase in the contractile ability was evident in the late stage hPSC-CMs when sarcomere length changes were measured during the contraction. Other functional characteristic parameters such as calcium uptake, action potential properties and cardiac gene expression profile of the late-stage hPSC-CMs closely re- 
sembled that of adult CMs.

Mimicking in vivo niche using tissue engineering approach: Because human cardiac muscle cells are exposed to pressure and electrical stimulation in vivo, they are structurally rod-shaped to minimize the impact. A method of improving the maturation of CMs through a cell culture system mimicking the natural environment is studied. As a result of culturing immature CMs by changing the surface of the cell culture dish to a patterned topography, a linear of myofibril was developed in the same direction as that of the substrate, and the distribution of the gap junction and the function of the conduction velocity improved (27). CMs are composed of 3D arrangement of interstitial fibroblast, blood vessel, extracellular matrix (ECM) and CMs (28). Therefore, in order to regulate the maturation of immature $\mathrm{CMs}$, a three-dimensional extracellular matrix capable of simulating the environment similar to myocardial tissue was prepared by tissue engineering techniques, which improved maturation of hPSC-CMs.

Electric stimulation: CMs form a synchronic structure with tissues with high electrical signal activity. In order to regulate the maturity of immature CMs by taking advantage of this property, the cells were cultured under the conditions of electric stimulation, and as a result, stable cell arrangement, intercellular synchronization and contractile capacity were all increased. In addition, the structure and function of mitochondria, sodium-calcium exchanger, action potential and conduction velocity were also improved (29).

\section{Application of hPSC-CMs}

It is widely recognized that hPSC-CMs can be used in the following applications; 1) disease modeling, 2) cell therapy development for treating acute myocardial infarction, 3) human cell based assays for arrhythmogenesis and cardiotoxicity evaluation of candidate molecules for drug discovery.

\section{Cardiac disease modeling}

hPSCs derived from patients with genetic heart diseases reflect individual genetic information, and CMs generated from such cells provide an accurate in vitro model of the diseases. This allows you gain sights into the cause of disorder and its consequences. Pathogenic studies of the human heart disease using an animal disease model has limitations in its accuracy because of differences in cell size, heart rate, and ion channel activity between the two species. Since the inception of iPSCs technology, CMs from patients' own iPSCs have been used to elucidate pathophysiology of representative genetic cardiac diseases such as Leopard syndrome, long QT syndrome, Timothy syndrome, Pompe disease, familial hypertrophic and dilated cardiomyopathy, and the genetic analysis and characterization of electrophysiological functions have been reported to reflect the characteristics of the diseases (30-36). Therefore, it is expected that cardiac disease modeling using hiPSC-CMs will be able to illuminate unseen pathological mechanisms of heart diseases for developing improved and efficient treatment methods.

\section{Cell therapy}

The first approved stem cell therapeutic product in the world, Hearticellgram-AMI is a bone marrow derived mesenchymal stem cells (MSCs) based therapy for treating acute myocardial infarction (47). A profusion of other clinical trials is currently taking place around the world to validate the feasibility of various other types of MSCs for treating myocardial infarction. In most of the trials,

Table 1. Pre-clinical and clinical studies of hPSC-CMs for treating cardiac injuries

\begin{tabular}{|c|c|c|c|c|c|}
\hline Experiments & Disease & Animal & Implantation & Results & References \\
\hline \multirow[t]{9}{*}{ Pre-clinical } & Complete AV block & Pig & Cell injection & Electromechanical integration in vivo pacing & $(37)$ \\
\hline & Acute myocardial & Rat & Gelatin Scaffold & Preservation of graft size $\uparrow$ & (38) \\
\hline & infarction & Mouse & Cell injection & $\mathrm{EF} \uparrow$, Infarct area $\downarrow$ & (39) \\
\hline & Chronic myocardial & Mouse & Cell injection & Infarct size $\downarrow$, Vascular density $\uparrow$ & $(40)$ \\
\hline & infarction & Rat & Cell injection & Graft volume $\uparrow$, Vascular density $\uparrow$ & $(41)$ \\
\hline & & Minipig & Cell sheet & $\mathrm{EF} \uparrow$, Vascularization & $(42)$ \\
\hline & & Mouse, Monkey & Cell injection & $\begin{array}{l}\text { Electrical coupling, Graft-host synchronization, } \\
\text { Non-fatal arrhythmias }\end{array}$ & $(43)$ \\
\hline & Cryo-injury & Guinea pig & Cell injection & Electrical coupling, Graft-host synchronization & (44) \\
\hline & Normal & Rat & Cardiac patch & Regeneration of host cardiomyocytes & (45) \\
\hline Clinical & Myocardial infarction & Human & Fibrin patch & $\mathrm{EF} \uparrow$, Graft-myocardial tissue & (46) \\
\hline
\end{tabular}


the safety of such therapies is consistently confirmed, but we are often left perplexed regarding to their efficacy. In the rare cases of therapeutic outcomes, the mode of therapeutic action is revealed to be indirect; through the paracrine effect of the stem cells secretory factors (48). Since the donor cells are expected to live only for a short period of time after transplantation, the potency of the paracrine effect remains questionable (49). The potential of using hPSC-CMs for treating myocardial infarction is manifested by pre-clinical and clinical studies (Table 1). In contrast to adult/fetal tissues derived MSCs, the transplanted hPSC-CMs functionally integrated into the injured cardiac tissue, and improved the function of cardiac muscles by synchronizing with the heart tissue of the recipient. The integrated cells remained viable up to 6 months post transplantation, and the observed functional improvement was also sustained for the same period of time. A significant milestone in PSCs research was reached when hPSC-CMs received the regulatory clearance to initiate human clinical trials for treating acute my- ocardial infarction in 2015 (46).

\section{Toxicity testing and drug screening}

Due to the difficulties associated with acquiring functionally mature human CMs, pharmaceutical developers have relied on animal CMs to screen and evaluate their candidate molecules for cardiotoxicity and arrhythmogenesis potential in preclinical studies. Despite extensive animal trials, there have been many cases of unsuccessful clinical trials due to the unseen cardiotoxicity in preclinical settings. Such failures underpin the inadequacy and fallibility of animal-based evaluations, and they are now increasingly considered as an obsolete platform for human application. hPSC-CMs provide considerable advantages for an alternative preclinical tool for providing better predictability of molecules in question prior to human clinical trials. Indeed, recent studies on the efficacy and toxicity of various drugs (Nifedipine, mitoTEMPO, Norepinephrine, etc.) have been carried out using CMs derived from hypertrophic cardiomyopathy (HCM), dilated

Table 2. Drug screening using patients' iPSC-CMs (y: year-old)

\begin{tabular}{|c|c|c|c|c|}
\hline Cardiovascular disease & Gene mutation & Donor & Drug test & References \\
\hline LQT-1 & KCNQ1 (R190Q) & 8 y, 42 y Male & Isoproterenol & (34) \\
\hline \multirow[t]{2}{*}{ LQT-2 } & $\mathrm{KCNH} 2(\mathrm{~A} 614 \mathrm{~V})$ & 28 y Female & Nifedipine, Pinacidil, Ranolazine & (50) \\
\hline & $\begin{array}{l}\text { KCNH2 (HERG), } \\
\text { A614V, G1681A }\end{array}$ & - & $\begin{array}{l}\text { Isoproterenol, Hydrochloride, Nifedipine, Ranolazine, } \\
\text { Dihydrochloride, Pinacidil monohydrate, Cisapride, } \\
\text { E-4031, Sotalol }\end{array}$ & (51) \\
\hline LQT-3 & SCN5A(F1473C) & - & Mexiletine, Flecainide & (52) \\
\hline \multirow[t]{2}{*}{ LQT-8 } & Cav1.2 (G406R) & - & $\cos 2 \cos 20$ & (32) \\
\hline & CACNA1CG1216A & - & Roscovitine & (51) \\
\hline \multirow[t]{2}{*}{ LQT } & $\mathrm{KCNH} 2$ & Male & Moxifloxacin & (53) \\
\hline & $\begin{array}{l}\text { NK2, SCN5A, KCNQ1, } \\
\text { CACNA1C, CALM1, } \\
\text { KCNE2, KCNH2, KCNJ5 }\end{array}$ & $\begin{array}{l}18 \sim 40 \text { y } \\
\text { Male, Female }\end{array}$ & Sotalol & (54) \\
\hline \multirow[t]{3}{*}{ CPVT } & RyR2 (S406L) & 24 y Female & Dantrolene & (55) \\
\hline & RyR2 (M4109R) & 30 y Female & Forskolin, Isoproterenol, Flecainide & (56) \\
\hline & $\begin{array}{l}\text { RYR2, S406L, CASQ2, } \\
\text { D307H }\end{array}$ & - & Dantrolene, Isoproterenol & (51) \\
\hline \multirow[t]{2}{*}{ DCM } & TNNT2, R173W & Male, Female & Norepinephrine & (57) \\
\hline & cTnT-R173W & 14 y Male & Omecamtiv mecarbil & (46) \\
\hline $\mathrm{HCM}$ & $\begin{array}{l}\text { MYH7 c.1988GNA; } \\
\text { p.R663H }\end{array}$ & 53 y Female & Isoproterenol, Propranolol, Verapamil & (35) \\
\hline Pompe disease & GAA & - & 3-MA, L-carnitine & (36) \\
\hline Barth syndrome & Tafazzin, BTH-H TAZ & - & mitoTEMPO & (58) \\
\hline $\begin{array}{l}\text { Familiar dilated } \\
\text { cardiomyopathy }\end{array}$ & TNNT2, R173W & - & Metoprolol & (51) \\
\hline $\mathrm{ARVD} / \mathrm{C}$ & PKP2 Plakophilin-2 & Male, Female & - & (30) \\
\hline Brugada syndrome/LQT-3 & E1784K SCN5A & 20 y, 34 y Male & - & (59) \\
\hline Brugada syndrome & SCN5A-1795insD & $\begin{array}{l}42 \text { y, } 67 \text { y Male, } \\
24 \text { y Female }\end{array}$ & - & (60) \\
\hline Cardiac arrhythmia & - & Male, Female & Tyrosine kinase inhibitors & (61) \\
\hline
\end{tabular}


cardiomyopathy (DCM), Barth syndrome (BTHS), Long QT syndrome (LQTS) 1, 2, 3, 8, catecholaminergic polymorphic ventricular tachycardia (CPVT) and arrhythmogenic right ventricular dysplasia (ARVC) patients, and their value as a cellular resource capable of coping with preclinical tests has been highlighted (Table 2). It is expected that the emergent hPSC-CMs based assays will continue to consolidate their presence in preclinical settings, which will lower the usage of animals and failure rate in clinical trials.

\section{Conclusion}

The outlook for hPSC-CMs application is promising: the human clinical trials for assessing safety and efficacy of hPSC-CMs for treating myocardial infarction are underway, a growing number of pharmaceutical companies have expressed their interests in endorsing hPSC-CMs for their preclinical testing, and pathogenic studies using heart disease patients' iPSC-CMs are leading the way to discover more effective treatments. For a widespread application of hPSC-CMs though, the following should be addressed by investigators. Although hPSC-CMs differentiation could be performed in various ways, more often than not, the consistency and efficiency of differentiation vary when different hPSCs lines are used due to the distinct inherent genetic characteristics of each cell line. Development of highly efficient universal differentiation methods would make CMs readily available for applications at reduced costs. Various maturation techniques for hPSC-CMs have been effectual in their own merits, but characteristics of matured hPSC-CMs still fall short of that derived from adult tissue. This precludes their application in drug development and screening since the way immature CMs respond to molecules will be different to that of adult CMs. Interestingly, from cell therapy perspective, CMs of neonatal, and fetal origins have demonstrated better survival then mature CMs upon transplantation. Thus, optimum maturation also needs to be identified for different applications of hPSC-CMs. Nonetheless, the future prospect of hPSC-CMs is exciting, and looks certain to cause a paradigm shift in discovering novel drugs and therapies for heart diseases.

\section{Acknowledgments}

This research was supported by grants from the Bio \& Medical Technology Development Program of the National Research Foundation (NRF) funded by the Korean government, MSIP (2015M3A9C7030091) and Korea National Institute of Health fund 4861-312-260 (2017-ER6101-00).

\section{Potential conflict of interest}

The authors have no conflicting financial interest.

\section{References}

1. Zhang J, Wilson GF, Soerens AG, Koonce $\mathrm{CH}, \mathrm{Yu} \mathrm{J}$, Palecek SP, Thomson JA, Kamp TJ. Functional cardiomyocytes derived from human induced pluripotent stem cells. Circ Res 2009;104:e30-e41

2. Bauwens CL, Peerani R, Niebruegge S, Woodhouse KA, Kumacheva E, Husain M, Zandstra PW. Control of human embryonic stem cell colony and aggregate size heterogeneity influences differentiation trajectories. Stem Cells 2008;26:2300-2310

3. Song K, Nam YJ, Luo X, Qi X, Tan W, Huang GN, Acharya A, Smith CL, Tallquist MD, Neilson EG, Hill JA, Bassel-Duby R, Olson EN. Heart repair by reprogramming non-myocytes with cardiac transcription factors. Nature 2012;485:599-604

4. Zhang J, Klos M, Wilson GF, Herman AM, Lian X, Raval KK, Barron MR, Hou L, Soerens AG, Yu J, Palecek SP, Lyons GE, Thomson JA, Herron TJ, Jalife J, Kamp TJ. Extracellular matrix promotes highly efficient cardiac differentiation of human pluripotent stem cells: the matrix sandwich method. Circ Res 2012;111:1125-1136

5. Burridge PW, Matsa E, Shukla P, Lin ZC, Churko JM, Ebert AD, Lan F, Diecke S, Huber B, Mordwinkin NM, Plews JR, Abilez OJ, Cui B, Gold JD, Wu JC. Chemically defined generation of human cardiomyocytes. Nat Methods 2014;11:855-860

6. Lian X, Bao X, Zilberter M, Westman M, Fisahn A, Hsiao C, Hazeltine LB, Dunn KK, Kamp TJ, Palecek SP. Chemically defined, albumin-free human cardiomyocyte generation. Nat Methods 2015;12:595-596

7. Mummery CL, Ward D, Passier R. Differentiation of human embryonic stem cells to cardiomyocytes by coculture with endoderm in serum-free medium. Curr Protoc Stem Cell Biol 2007 doi: 10.1002/9780470151808.sc01f02s2

8. Kehat I, Gepstein A, Spira A, Itskovitz-Eldor J, Gepstein L. High-resolution electrophysiological assessment of human embryonic stem cell-derived cardiomyocytes: a novel in vitro model for the study of conduction. Circ Res 2002; 91:659-661

9. Kempf H, Olmer R, Kropp C, Rückert M, Jara-Avaca $M$, Robles-Diaz D, Franke A, Elliott DA, Wojciechowski D, Fischer M, Roa Lara A, Kensah G, Gruh I, Haverich A, Martin U, Zweigerdt R. Controlling expansion and cardiomyogenic differentiation of human pluripotent stem cells in scalable suspension culture. Stem Cell Reports 2014;3:1132-1146

10. Doevendans PA, Kubalak SW, An RH, Becker DK, Chien KR, Kass RS. Differentiation of cardiomyocytes in floating embryoid bodies is comparable to fetal cardiomyocytes. J Mol Cell Cardiol 2000;32:839-851

11. Xu C, Police S, Hassanipour M, Gold JD. Cardiac bodies: a novel culture method for enrichment of cardiomyocytes 
derived from human embryonic stem cells. Stem Cells Dev 2006;15:631-639

12. Laflamme MA, Chen KY, Naumova AV, Muskheli V, Fugate JA, Dupras SK, Reinecke H, Xu C, Hassanipour M, Police S, O'Sullivan C, Collins L, Chen Y, Minami E, Gill EA, Ueno S, Yuan C, Gold J, Murry CE. Cardiomyocytes derived from human embryonic stem cells in pro-survival factors enhance function of infarcted rat hearts. Nat Biotechnol 2007;25:1015-1024

13. Yang L, Soonpaa MH, Adler ED, Roepke TK, Kattman SJ, Kennedy M, Henckaerts E, Bonham K, Abbott GW, Linden RM, Field LJ, Keller GM. Human cardiovascular progenitor cells develop from a $\mathrm{KDR}+$ embryonic-stem-cell-derived population. Nature 2008;453:524-528

14. Kattman SJ, Witty AD, Gagliardi M, Dubois NC, Niapour M, Hotta A, Ellis J, Keller G. Stage-specific optimization of activin/nodal and BMP signaling promotes cardiac differentiation of mouse and human pluripotent stem cell lines. Cell Stem Cell 2011;8:228-240

15. Dubois NC, Craft AM, Sharma P, Elliott DA, Stanley EG, Elefanty AG, Gramolini A, Keller G. SIRPA is a specific cell-surface marker for isolating cardiomyocytes derived from human pluripotent stem cells. Nat Biotechnol 2011;29:1011-1018

16. Uosaki H, Fukushima H, Takeuchi A, Matsuoka S, Nakatsuji N, Yamanaka S, Yamashita JK. Efficient and scalable purification of cardiomyocytes from human embryonic and induced pluripotent stem cells by VCAM1 surface expression. PLoS One 2011;6:e23657

17. Anderson D, Self T, Mellor IR, Goh G, Hill SJ, Denning C. Transgenic enrichment of cardiomyocytes from human embryonic stem cells. Mol Ther 2007;15:2027-2036

18. Elliott DA, Braam SR, Koutsis K, Ng ES, Jenny R, Lagerqvist EL, Biben C, Hatzistavrou T, Hirst CE, Yu QC, Skelton RJ, Ward-van Oostwaard D, Lim SM, Khammy O, Li X, Hawes SM, Davis RP, Goulburn AL, Passier R, Prall OW, Haynes JM, Pouton CW, Kaye DM, Mummery CL, Elefanty AG, Stanley EG. NKX2-5(eGFP/w) hESCs for isolation of human cardiac progenitors and cardiomyocytes. Nat Methods 2011;8:1037-1040

19. Ritner C, Wong SS, King FW, Mihardja SS, Liszewski W, Erle DJ, Lee RJ, Bernstein HS. An engineered cardiac reporter cell line identifies human embryonic stem cell-derived myocardial precursors. PLoS One 2011;6:e16004

20. Tohyama S, Hattori F, Sano M, Hishiki T, Nagahata Y, Matsuura T, Hashimoto H, Suzuki T, Yamashita H, Satoh Y, Egashira T, Seki T, Muraoka N, Yamakawa H, Ohgino Y, Tanaka T, Yoichi M, Yuasa S, Murata M, Suematsu M, Fukuda K. Distinct metabolic flow enables large-scale purification of mouse and human pluripotent stem cell-derived cardiomyocytes. Cell Stem Cell 2013;12:127-137

21. Zhu WZ, Xie Y, Moyes KW, Gold JD, Askari B, Laflamme MA. Neuregulin/ErbB signaling regulates cardiac subtype specification in differentiating human embryonic stem cells. Circ Res 2010;107:776-786

22. Ziman AP, Gómez-Viquez NL, Bloch RJ, Lederer WJ.
Excitation-contraction coupling changes during postnatal cardiac development. J Mol Cell Cardiol 2010;48:379-386

23. Angst BD, Khan LU, Severs NJ, Whitely K, Rothery S, Thompson RP, Magee AI, Gourdie RG. Dissociated spatial patterning of gap junctions and cell adhesion junctions during postnatal differentiation of ventricular myocardium. Circ Res 1997;80:88-94

24. Peters NS, Severs NJ, Rothery SM, Lincoln C, Yacoub MH, Green CR. Spatiotemporal relation between gap junctions and fascia adherens junctions during postnatal development of human ventricular myocardium. Circulation 1994;90:713-725

25. Lopaschuk GD, Jaswal JS. Energy metabolic phenotype of the cardiomyocyte during development, differentiation, and postnatal maturation. J Cardiovasc Pharmacol 2010;56:130140

26. Lundy SD, Zhu WZ, Regnier M, Laflamme MA. Structural and functional maturation of cardiomyocytes derived from human pluripotent stem cells. Stem Cells Dev 2013;22: 1991-2002

27. Heidi Au HT, Cui B, Chu ZE, Veres T, Radisic M. Cell culture chips for simultaneous application of topographical and electrical cues enhance phenotype of cardiomyocytes. Lab Chip 2009;9:564-575

28. Zimmermann WH, Schneiderbanger K, Schubert P, Didié M, Münzel F, Heubach JF, Kostin S, Neuhuber WL, Eschenhagen T. Tissue engineering of a differentiated cardiac muscle construct. Circ Res 2002;90:223-230

29. Martherus RS, Vanherle SJ, Timmer ED, Zeijlemaker VA, Broers JL, Smeets HJ, Geraedts JP, Ayoubi TA. Electrical signals affect the cardiomyocyte transcriptome independently of contraction. Physiol Genomics 2010;42A:283-289

30. Kim C, Wong J, Wen J, Wang S, Wang C, Spiering S, Kan NG, Forcales S, Puri PL, Leone TC, Marine JE, Calkins H, Kelly DP, Judge DP, Chen HS. Studying arrhythmogenic right ventricular dysplasia with patient-specific iPSCs. Nature 2013;494:105-110

31. Olivetti G, Cigola E, Maestri R, Corradi D, Lagrasta C, Gambert SR, Anversa P. Aging, cardiac hypertrophy and ischemic cardiomyopathy do not affect the proportion of mononucleated and multinucleated myocytes in the human heart. J Mol Cell Cardiol 1996;28:1463-1477

32. Yazawa M, Hsueh B, Jia X, Pasca AM, Bernstein JA, Hallmayer J, Dolmetsch RE. Using induced pluripotent stem cells to investigate cardiac phenotypes in Timothy syndrome. Nature 2011;471:230-234

33. Carvajal-Vergara X, Sevilla A, D'Souza SL, Ang YS, Schaniel C, Lee DF, Yang L, Kaplan AD, Adler ED, Rozov R, Ge Y, Cohen N, Edelmann LJ, Chang B, Waghray A, Su J, Pardo S, Lichtenbelt KD, Tartaglia M, Gelb BD, Lemischka IR. Patient-specific induced pluripotent stem-cell-derived models of LEOPARD syndrome. Nature 2010;465:808-812

34. Moretti A, Bellin M, Welling A, Jung CB, Lam JT, Bott-Flügel L, Dorn T, Goedel A, Höhnke C, Hofmann F, Seyfarth M, Sinnecker D, Schömig A, Laugwitz KL. 
Patient-specific induced pluripotent stem-cell models for long-QT syndrome. N Engl J Med 2010;363:1397-1409

35. Lan F, Lee AS, Liang P, Sanchez-Freire V, Nguyen PK, Wang L, Han L, Yen M, Wang Y, Sun N, Abilez OJ, Hu S, Ebert AD, Navarrete EG, Simmons CS, Wheeler M, Pruitt B, Lewis R, Yamaguchi Y, Ashley EA, Bers DM, Robbins RC, Longaker MT, Wu JC. Abnormal calcium handling properties underlie familial hypertrophic cardiomyopathy pathology in patient-specific induced pluripotent stem cells. Cell Stem Cell 2013;12:101-113

36. Huang HP, Chen PH, Hwu WL, Chuang CY, Chien YH, Stone L, Chien CL, Li LT, Chiang SC, Chen HF, Ho HN, Chen $\mathrm{CH}$, Kuo HC. Human Pompe disease-induced pluripotent stem cells for pathogenesis modeling, drug testing and disease marker identification. Hum Mol Genet 2011;20:4851-4864

37. Kehat I, Khimovich L, Caspi O, Gepstein A, Shofti R, Arbel G, Huber I, Satin J, Itskovitz-Eldor J, Gepstein L. Electromechanical integration of cardiomyocytes derived from human embryonic stem cells. Nat Biotechnol 2004; 22:1282-1289

38. Mihic A, Li J, Miyagi Y, Gagliardi M, Li SH, Zu J, Weisel RD, Keller G, Li RK. The effect of cyclic stretch on maturation and $3 \mathrm{D}$ tissue formation of human embryonic stem cell-derived cardiomyocytes. Biomaterials 2014;35:2798-2808

39. Sanchez-Freire V, Lee AS, Hu S, Abilez OJ, Liang P, Lan F, Huber BC, Ong SG, Hong WX, Huang M, Wu JC. Effect of human donor cell source on differentiation and function of cardiac induced pluripotent stem cells. J Am Coll Cardiol 2014;64:436-448

40. Yeghiazarians Y, Gaur M, Zhang Y, Sievers RE, Ritner C, Prasad M, Boyle A, Bernstein HS. Myocardial improvement with human embryonic stem cell-derived cardiomyocytes enriched by p38MAPK inhibition. Cytotherapy 2012;14: 223-231

41. Luo J, Weaver MS, Cao B, Dennis JE, Van Biber B, Laflamme MA, Allen MD. Cobalt protoporphyrin pretreatment protects human embryonic stem cell-derived cardiomyocytes from hypoxia/reoxygenation injury in vitro and increases graft size and vascularization in vivo. Stem Cells Transl Med 2014;3:734-744

42. Kawamura M, Miyagawa S, Miki K, Saito A, Fukushima S, Higuchi T, Kawamura T, Kuratani T, Daimon T, Shimizu T, Okano T, Sawa Y. Feasibility, safety, and therapeutic efficacy of human induced pluripotent stem cell-derived cardiomyocyte sheets in a porcine ischemic cardiomyopathy model. Circulation 2012;126(11 Suppl 1):S29-S37

43. Chong JJ, Yang X, Don CW, Minami E, Liu YW, Weyers JJ, Mahoney WM, Van Biber B, Cook SM, Palpant NJ, Gantz JA, Fugate JA, Muskheli V, Gough GM, Vogel KW, Astley CA, Hotchkiss CE, Baldessari A, Pabon L, Reinecke H, Gill EA, Nelson V, Kiem HP, Laflamme MA, Murry CE. Human embryonic-stem-cell-derived cardiomyocytes regenerate non-human primate hearts. Nature 2014;510:273277

44. Shiba Y, Filice D, Fernandes S, Minami E, Dupras SK,
Biber BV, Trinh P, Hirota Y, Gold JD, Viswanathan M, Laflamme MA. Electrical Integration of Human Embryonic Stem Cell-Derived Cardiomyocytes in a Guinea Pig Chronic Infarct Model. J Cardiovasc Pharmacol Ther 2014;19:368381

45. Sugiura T, Hibino N, Breuer CK, Shinoka T. Tissue-engineered cardiac patch seeded with human induced pluripotent stem cell derived cardiomyocytes promoted the regeneration of host cardiomyocytes in a rat model. J Cardiothorac Surg 2016;11:163

46. Menasché P, Vanneaux V, Hagège A, Bel A, Cholley B, Cacciapuoti I, Parouchev A, Benhamouda N, Tachdjian G, Tosca L, Trouvin JH, Fabreguettes JR, Bellamy V, Guillemain R, Suberbielle Boissel C, Tartour E, Desnos M, Larghero J. Human embryonic stem cell-derived cardiac progenitors for severe heart failure treatment: first clinical case report. Eur Heart J 2015;36:2011-2017

47. Lee JW, Lee SH, Youn YJ, Ahn MS, Kim JY, Yoo BS, Yoon J, Kwon W, Hong IS, Lee K, Kwan J, Park KS, Choi D, Jang YS, Hong MK. A randomized, open-label, multicenter trial for the safety and efficacy of adult mesenchymal stem cells after acute myocardial infarction. J Korean Med Sci 2014;29:23-31

48. Lunde K, Solheim S, Aakhus S, Arnesen H, Abdelnoor M, Egeland T, Endresen K, Ilebekk A, Mangschau A, Fjeld JG, Smith HJ, Taraldsrud E, Grøgaard HK, Bjørnerheim R, Brekke M, Müller C, Hopp E, Ragnarsson A, Brinchmann JE, Forfang K. Intracoronary injection of mononuclear bone marrow cells in acute myocardial infarction. $\mathrm{N}$ Engl J Med 2006;355:1199-1209.

49. Hofmann M, Wollert KC, Meyer GP, Menke A, Arseniev L, Hertenstein B, Ganser A, Knapp WH, Drexler H. Monitoring of bone marrow cell homing into the infarcted human myocardium. Circulation 2005;111:2198-2202

50. Itzhaki I, Maizels L, Huber I, Zwi-Dantsis L, Caspi O, Winterstern A, Feldman O, Gepstein A, Arbel G, Hammerman H, Boulos M, Gepstein L. Modelling the long QT syndrome with induced pluripotent stem cells. Nature 2011; 471:225-229

51. Csöbönyeiová $M$, Polák Š, Danišovič L. Toxicity testing and drug screening using iPSC-derived hepatocytes, cardiomyocytes, and neural cells. Can J Physiol Pharmacol 2016;94:687-694

52. Terrenoire C, Wang K, Tung KW, Chung WK, Pass RH, Lu JT, Jean JC, Omari A, Sampson KJ, Kotton DN, Keller G, Kass RS. Induced pluripotent stem cells used to reveal drug actions in a long QT syndrome family with complex genetics. J Gen Physiol 2013;141:61-72

53. Shinozawa T, Nakamura K, Shoji M, Morita M, Kimura M, Furukawa H, Ueda H, Shiramoto M, Matsuguma K, Kaji Y, Ikushima I, Yono M, Liou SY, Nagai H, Nakanishi A, Yamamoto K, Izumo S. Recapitulation of clinical individual susceptibility to drug-induced QT prolongation in healthy subjects using iPSC-derived cardiomyocytes. Stem Cell Reports 2017;8:226-234

54. Stillitano F, Hansen J, Kong CW, Karakikes I, Funck- 
Brentano C, Geng L, Scott S, Reynier S, Wu M, Valogne Y, Desseaux C, Salem JE, Jeziorowska D, Zahr N, Li R, Iyengar R, Hajjar RJ, Hulot JS. Modeling susceptibility to drug-induced long QT with a panel of subject-specific induced pluripotent stem cells. Elife 2017;6 doi: 10.7554/ eLife. 19406

55. Jung CB, Moretti A, Mederos y Schnitzler M, Iop L, Storch U, Bellin M, Dorn T, Ruppenthal S, Pfeiffer S, Goedel A, Dirschinger RJ, Seyfarth M, Lam JT, Sinnecker D, Gudermann T, Lipp P, Laugwitz KL. Dantrolene rescues arrhythmogenic RYR2 defect in a patient-specific stem cell model of catecholaminergic polymorphic ventricular tachycardia. EMBO Mol Med 2012;4:180-191

56. Itzhaki I, Maizels L, Huber I, Gepstein A, Arbel G, Caspi O, Miller L, Belhassen B, Nof E, Glikson M, Gepstein L. Modeling of catecholaminergic polymorphic ventricular tachycardia with patient-specific human-induced pluripotent stem cells. J Am Coll Cardiol 2012;60:990-1000

57. Sun N, Yazawa M, Liu J, Han L, Sanchez-Freire V, Abilez OJ, Navarrete EG, Hu S, Wang L, Lee A, Pavlovic A, Lin S, Chen R, Hajjar RJ, Snyder MP, Dolmetsch RE, Butte MJ, Ashley EA, Longaker MT, Robbins RC, Wu JC. Patient-specific induced pluripotent stem cells as a model for familial dilated cardiomyopathy. Sci Transl Med 2012;4:130ra47

58. Wang G, McCain ML, Yang L, He A, Pasqualini FS, Agarwal A, Yuan H, Jiang D, Zhang D, Zangi L, Geva J,
Roberts AE, Ma Q, Ding J, Chen J, Wang DZ, Li K, Wang J, Wanders RJ, Kulik W, Vaz FM, Laflamme MA, Murry CE, Chien KR, Kelley RI, Church GM, Parker KK, Pu WT. Modeling the mitochondrial cardiomyopathy of Barth syndrome with induced pluripotent stem cell and hearton-chip technologies. Nat Med 2014;20:616-623

59. Okata S, Yuasa S, Suzuki T, Ito S, Makita N, Yoshida T, Li M, Kurokawa J, Seki T, Egashira T, Aizawa Y, Kodaira M, Motoda C, Yozu G, Shimojima M, Hayashiji N, Hashimoto H, Kuroda Y, Tanaka A, Murata M, Aiba T, Shimizu W, Horie M, Kamiya K, Furukawa T, Fukuda K. Embryonic type $\mathrm{Na}+$ channel $\beta$-subunit, $\mathrm{SCN} 3 \mathrm{~B}$ masks the disease phenotype of Brugada syndrome. Sci Rep 2016;6:34198

60. Veerman CC, Mengarelli I, Guan K, Stauske M, Barc J, Tan HL, Wilde AA, Verkerk AO, Bezzina CR. hiPSC-derived cardiomyocytes from Brugada Syndrome patients without identified mutations do not exhibit clear cellular electrophysiological abnormalities. Sci Rep 2016;6:30967

61. Sharma A, Burridge PW, McKeithan WL, Serrano R, Shukla P, Sayed N, Churko JM, Kitani T, Wu H, Holmström A, Matsa E, Zhang Y, Kumar A, Fan AC, Del Álamo JC, Wu SM, Moslehi JJ, Mercola M, Wu JC. High-throughput screening of tyrosine kinase inhibitor cardiotoxicity with human induced pluripotent stem cells. Sci Transl Med 2017;9 doi: 10.1126/scitranslmed.aaf2584 